\title{
Dictatorial Rule and Sexual Politics in Argentina: The Case of the Frente de Liberación Homosexual, 1967-1976
}

\author{
Pablo Ben and Santiago Joaquin Insausti
}

\begin{abstract}
The Frente de Liberación Homosexual (FLH, 1967-1976) was the first political movement of homosexual men in Argentina. Despite its short life span, this organization set the ground for future developments. The FLH emerged in the context of increasing authoritarianism rather than being the result of a transition to democracy. The relationship with homophobic Peronists and left-wing traditions was, paradoxically, crucial for the emergence of the FLH. Most homosexual activists came from the Left, and they understood homosexual liberation as one aspect of the struggle against capitalism. These activists were highly critical of anticapitalist politics as it existed in Argentina at the time, but they also actively sought to become allies of the expanding New Left during the period. Eventually, however, the 1976-1983 military dictatorship made all forms of dissidence impossible, and the FLH had to dissolve.
\end{abstract}

\section{Introduction}

$\mathrm{T}$ he Frente de Liberación Homosexual (FLH) was the first political movement comprised predominantly of homosexual men in Argentina. It was a coalition of smaller groups from a wide variety of ideological backgrounds, even if a left-wing and anticapitalist approach prevailed throughout the collective. Under the name Nuestro Mundo, or Our World, the coalition's first group was formed in the late ig6os. The other groups would emerge independently in the following years. By r97 I a group called Profesionales, formed by professional writers, aligned with Nuestro Mundo to form the FLH. New organizations would join in the coming years, including the consciousnessraising group Alborada (Dawn), a lesbian group known as Safo, the anarchist Bandera Negra (Black Banner), the radical student collective Eros, and three religious groups of different Christian denominations: Emmanuel, Católicos,

A number of activists and scholars have facilitated our research by preserving the historical documentation of the LGBT movement in Argentina and granting us access to this crucial information. We want to specially thank Zelmar Acevedo, He'ctor Anabitarte, Marcelo Benitez, Jorge Giacosa, and Sergio Pe'rez for their help. Without them this essay and the very history of queer activism that it tells would not be possible. 
and Grupo Cristiano. ${ }^{1}$ Emerging in times of intense political turmoil, the FLH had a short life span, ending abruptly in 1976 , before the start of the most brutal military dictatorship in the history of Argentina. The period from the late I960s to the early I970s, in which the FLH came into existence, was quite repressive and authoritarian, even if the actions of the military during those years paled in comparison to what the ruling military junta would do after i 976 , when systematic state terrorism and mass murder began.

The history of political polarization, civilian radicalization, and military authoritarianism in Argentina constitutes a fundamental aspect of our understanding of the internal history of the FLH. This relationship between the FLH and Argentine politics from the late ig6os to the early i970s has been lost because, for the most part, previous studies of the movement have been anecdotal or have concentrated on the magazine Somos, which was published by the FLH between December 1973 and January 1976.2 During these last three years of the FLH's history, however, the organization was in decline and its activists were concerned with their own survival rather than political activity. The height of its political activity came before I973, when the FLH expanded, became publicly visible, and built multiple alliances with other organizations. This early period of success and intense activism has been overlooked because scholars have focused on discourse analysis of what the FLH published rather than its history of political activity. Based on an exhaustive examination of newly available internal documents from the FLH since the late I96os, this article considers the changing political strategies of the movement and how these strategies were shaped by gender, sexuality, and politics in the late Cold War era. ${ }^{3}$

Seen from this comprehensive point of view, two aspects of the FLH's history that are similar to comparable movements in Latin America stand out: the struggle against authoritarianism, and the foundational influence of leftwing and working-class politics. Whereas many LGBT movements in other regions of the world have resulted from transitions to democracy, the FLH was

I. Although the vast majority of the FLH's members were homosexual men, a few women participated in some of its groups. Safo was an exclusively lesbian group composed of only two women. The alliance with feminism was crucial for the development of the FLH's sexual politics, as we explain later in this article.

2. Vespucci, "Explorando"; Felitti, "En defensa"; Rapisardi and Modarelli, Fiestas; Bazán, Historia; Sebreli, Escritos. For a contextual analysis of the history of sexual and gender identities in Argentina during this period, see Cosse, Felitti, and Manzano, Los '6o; Cosse, Pareja; Andújar et al., De minifaldas; Felitti, La revolución.

3. Some aspects of this have been briefly suggested in Green and Babb, "Introduction." 
born at a moment when authoritarianism was on the rise in Latin America. ${ }^{4}$ Moreover, none of the groups forming the FLH thought democratization was the most important goal. And this was the case even when some of the movement's goals, such as ending police harassment, involved demanding democratic rights. For the most part, the FLH framed the achievement of those democratic rights within the context of a leftist and anti-imperialist notion of liberation as a collective struggle against oppression and capitalism rather than a defense of individual freedom. The ending of police harassment of homosexuals was probably the most important demand shared by the different groups, but nobody in the FLH discussed this issue using the political vocabulary associated with human or civil rights, democracy, the law, or minority politics. Instead, left-wing and working-class politics played a constitutive part in the FLH's formation and subsequent history. This is an important aspect of the FLH that provides an alternative and unexplored view of the relationship between gender/ sexual and left-wing politics in Latin America during the late Cold War era.

Most of the recent historiography exploring this connection has emphasized the male chauvinist and homophobic character of working-class and leftwing politics during the period. ${ }^{5}$ Although that trend is undeniable, the almost exclusive historiographic focus on assessing prejudice among activists and organizations on the left has often obscured the fact that the first wave of LGBT activists not only came from the Left and at times unions but also aimed at becoming an integral part of anticapitalist politics. But the way that the FLH faced Argentina's increasingly authoritarian context does not just offer a chance to rethink the relationship between democracy and left-wing, working-class, and LGBT politics. In addition, this history of the FLH provides a unique opportunity to study the late Cold War era in Latin America from a new angle that illuminates the relationship between sexuality, civil society, and the state. In the r960s and I970s, sexual morality in Argentina became liberalized while the

4. The recent scholarship on the topic has often implicitly associated democracy with the rise of LGBT movements throughout the world, which is often accurate. See, for instance, Brown, “'Con discriminación'”; Seidman, "Gendered Citizenship”; Corrales and Pecheny, Politics; and some of the essays in Drucker, Different Rainbows; Adam, Duyvendak, and Krouwel, Global Emergence.

5. Some scholars stress the presence of a homophobic male identity that excluded women and gays as constitutive of late Cold War left-wing politics in Latin America: see Mallon, "Barbudos"; Manzano, "Sex." Others claim that homophobia and male chauvinism stemmed from the isolation driven by the clandestine conditions of civilian politics during the period and that both were often challenged by individuals even if they remained hegemonic: for instance, see Green, “"Who Is the Macho' "; Cosse, "Infidelities”; Oberti, "La moral." 
military state adopted an authoritarian response to political radicalization that often included control of civilian morality. The FLH was part of a wider field of grassroots activism attempting to counteract the state's social control of politics and daily life. In this sense, rather than developing a notion of homosexuals as an oppressed minority, the FLH during most of its existence believed that the oppression they suffered was a more intense version of what happened to all civilians, both heterosexual and homosexual. It is in this context that the FLH shared goals and ideologies with other movements, even though the attempts to build alliances with them often met with rejection. The history of this ambivalent relation between organized homosexual men and other political forces began with the emergence of the FLH's first group in the late ig6os.

\section{Authoritarianism and the Birth of Nuestro Mundo}

Known as Nuestro Mundo, the first group that would eventually comprise the FLH emerged in the midst of rising union activism. The military had deposed Juan Perón in 1955, after which real wages declined. As a response, Peronist unions regularly organized strikes in the subsequent years and throughout the i $960 s$. The demand was for more than higher wages; unions also rejected military intervention in civilian politics and the ban on the Peronist Party, in effect from 1955 to $1973 .{ }^{6}$ The men who would eventually create Nuestro Mundo acquired a political worldview in this context. They were organizers in the Federación de Obreros y Empleados de Correos y Telecomunicaciones, a union of postal service workers. By the mid-I96os they began to identify each other as homosexual men and to socialize, gathering in cafés after union meetings. For many years their conversations were informal, and at first they did not even consider the possibility of organizing as homosexual men. When talking about politics during this period, they would discuss the unions' agenda, not gender and sexuality. As authoritarianism rose in the second half of the I960s, however, these men began to consider politics vis-à-vis their sexual identity. ${ }^{7}$ Yet unions continued to play an unwitting but crucial role in the emergence of the men's new political interest.

Unions both obstructed and facilitated the formation of this political group of homosexual men. As was the case in many working-class and left-wing political organizations throughout Latin America during the late Cold War era, working-class struggle and resistance by Argentine unions against the military

\footnotetext{
6. For the major events in the political history of Argentina, see Rock, Argentina.

7. Héctor Anabitarte, interview by Santiago Joaquin Insausti, Buenos Aires, 5 Sept. 2006.
} 
were presented as manifestations of manhood. This masculinization of political action did not create the most welcoming environment for homosexuals to organize as such. Symbolically, the presence of homosexuality constituted a challenge to the traditional male gender role anchoring union solidarity and workers' struggle. ${ }^{8}$ Yet daily life in the unions and among workers was prejudiced but not overtly hostile to homosexuality; a live-and-let-live attitude seemed to prevail.

An analysis of both written and oral evidence suggests a pattern of deeply ambivalent attitudes toward homosexuality. Pathologization of homosexuality, and more specifically rejection of male homosexual promiscuity, was hegemonic in Argentine society, but homosexual men were able to enjoy a life full of opportunities for sex without being ostracized from their neighborhoods or jobs. ${ }^{9}$ Gay men who recalled their lives in the 1960 s during interviews that took place in the 2000 s explicitly stressed how they were perceived as deviants. The way that this stress becomes one of the main narrative threads structuring the interviews, however, suggests a high degree of scripting in the 2000 s about the experience that these men had in the $1960 s .{ }^{10}$ For instance, the interviews refer to participation in carnival and neighborhood parties where effeminate homosexual men and straight youth socialized in the open and at times engaged in sexual activities. ${ }^{11}$ Upper-middle-class professionals were afraid of sexual scandals being the cause of losing their jobs, but the interviews with blue-collar workers offer no evidence of comparable fear. ${ }^{12}$ Written records show a similar pattern. Héctor Anabitarte, the eventual leader of Nuestro Mundo, provided a number of examples of tolerance that illustrate the situation in the workplace, some neighborhoods, and the unions. For instance, he recalled the experience of a person who had been assigned the male gender at birth and wanted to live as a woman. At her request, the manager at the post office where she worked allowed her to wear female clothes and use a female name. ${ }^{13}$ Anabitarte himself told his boss at a news agency that he liked men and suffered no consequences. ${ }^{14}$ In his poetry, Néstor Perlongher alludes to ubiquitous sex in the public sphere

\section{James, Resistance.}

9. Interviews, 2005, Sociedad de Integración Gay Lésbica Argentina, Buenos Aires (hereafter cited as SIGLA); Malva, interview by Santiago Joaquin Insausti and Soledad Cutuli, 7 Mar. 20 I 2.

Io. For further analysis of 2000 s views about the i96os, see Insausti, "De maricas."

I I. Interview, 2005, SIGLA; Malva, interview.

I2. Interviews, 2005, SIGLA.

I3. Anabitarte, Estrechamente, i 6.

I4. Anabitarte, Nadie, 32. 
despite police persecution. ${ }^{15}$ These references to free socialization and absence of persecution in the workplace do not constitute a systematic survey that could offer conclusive evidence proving lack of discrimination. However, the interviews conducted in the 2000 s and some of the written evidence suggest that the narrative of victimhood was probably overstated and that homosexual men had access to a degree of integration in their neighborhoods and workplaces, especially in working-class suburbs. ${ }^{16}$

This relative tolerance was probably due to the peculiarities of Cold War homophobia in Argentina and perhaps also in the rest of Latin America. Whereas in the United States McCarthyism had systematically promoted employment purges affecting homosexual men, no comparable phenomenon took place south of the Rio Grande. ${ }^{17}$ In Latin America the challenge to the lives of homosexual men was more likely to come from police harassment than their workplace. ${ }^{18}$ In fact, solidarity with those whose jobs were at stake was pivotal within the Argentine unions, and it probably helped homosexual men feel safer than they would have in the United States. ${ }^{19}$ Those who would join Nuestro Mundo had no difficulty identifying one another and socializing together. Moreover, they feared no retaliation for associating as homosexual men. The union did not isolate them from each other. On the contrary, it was through union activities that they were able to connect, explore their shared lives, and eventually embrace sexual politics. ${ }^{20}$

Union life and the rise of left-wing politics in the late I96os also helped cement the bond between these homosexual men in other ways. For example, even though they had very different political views, the future members of Nuestro Mundo gained from participation in the union as activists a common ground to negotiate differences that might have otherwise proven irreconcilable. ${ }^{21}$ Most important, unions and left-wing organizations played a positive role in the formation of homosexual politics because their organized response

I5. Perlongher, Evita; and the poems "Por qué seremos tan hermosas" (I980) and "Albañiles desnudos" (1992), in Perlongher, Poemas, 55, 3 о I.

I6. Insausti, "De maricas." Malva, a Chilean effeminate man who chose a woman's name and migrated to Argentina in the I940s, recalls both police persecution and integration to life in the neighborhoods during the I96os in her autobiography Malva, Mi recordatorio. For an excellent and detailed analysis of the presence of furtive sex in the public sphere during this era, see Fernández, "Sociabilidad homoerótica."

I 7. Johnson, Lavender Scare.

I8. Insausti, "Los cuatrocientos homosexuales desaparecidos." See also Gentili, Me va a tener.

I9. Schneider, Los compañeros.

20. Anabitarte, interview.

2 I. Anabitarte, Nadie, 22-32. 
to growing political authoritarianism in the I960s served as a model for homosexual men. During those years the Argentine military sought to restrict political activity, attack unions, and launch intensified police persecution of homosexual men. ${ }^{22}$ Ultimately unions, left-wing organizations, and homosexual men faced a common enemy: the military. Homosexual men, however, had never organized to stop police harassment. Unions and the Left, by contrast, had years of experience in resisting the military rule that was backing such harassment. This is why the future members of Nuestro Mundo were inspired by the resistance that both unions and the Left presented to the increasingly repressive regime.

The exact moment when socializing transitioned to political organization is difficult to pinpoint. There are different claims regarding the creation of Nuestro Mundo. Anabitarte stated that it was created in 1967 , but another famous activist from the FLH, Néstor Perlongher, believed that it was formed in I969. 23 The chronology provided by Anabitarte is backed by other materials published by Nuestro Mundo. ${ }^{24}$ According to Anabitarte, the ${ }_{9} 967$ foundation took place in the house of union activist Luis Troitiño. However, the men who gathered at Troitiño's place had known each other for years, and it seems unlikely that they organized a first meeting without having ever discussed homosexual politics before. The idea of a first meeting seems to stem from the need to construct a foundational reference. The transition from socializing to formal organization was probably more gradual than the activists recall.

Focusing on Nuestro Mundo's founding date, however, distracts from exploring the role of clandestinity in the group's formation as a political organization. As Juan Carlos Onganía's dictatorship banned politics among civilians between 1966 and 1969, underground politics increased. A new and varied wave of left-wing and radical groups with affiliations ranging from Trotskyism to Maoism, Christian Third Worldism, Guevarism, left-wing Peronism, and feminism was on the rise. Like participants in these other groups, the members of Nuestro Mundo needed a private space where they could meet secretly and plan an expansion in membership. The clandestine character of their first

22. See, for instance, Anzorena, Tiempo; Manzano, "Sexualizing Youth." For analysis of the rise in police persecution of homosexual men, see Bazán, Historia, 3 Io-I 2; Sebreli, "Historia secreta," 324; Marcelo Benitez, "Historia de la represión sexual en Argentina," El Porteño (Buenos Aires), Apr. I984, pp. 62-65.

23. Anabitarte, Nadie, 33; Perlongher, "Historia," 77.

24. One Nuestro Mundo bulletin published in December 1970 is dated as part of a series started three years before, and another, published in 1974 , is dated as belonging to the series' seventh year. (This and other FLH periodicals can be consulted at the Centro de Documentación e Investigación de la Cultura de Izquierdas.) 
meetings in the suburban house of Luis Troitiño, located about an hour's drive south of Buenos Aires, would be seminal. Troitiño had a personal conflict with a neighbor; thus when this neighbor saw the men arriving next door for one of their meetings, she called the police. When the police arrived, they accused the ten men of engaging in illegal gambling. The fact that homosexual politics was beyond the police's wildest imagination gave Nuestro Mundo's members an advantage and saved them from potentially harsher treatment. ${ }^{25}$ Although they only spent one night at the police station, they were no longer just a group of friends socializing together. ${ }^{26}$

In the first years of Nuestro Mundo, holding meetings continued to pose a major challenge. They tried to meet at an old railway signal box where one of them worked. However, discussions were interrupted every few minutes when everyone had to crouch to avoid being seen by passing trains. ${ }^{27}$ Later a leftist nun offered to host them at a Catholic school. Although seemingly ideal as a hiding place, even this location turned out to be dangerous. They were forced to find yet another place when the Argentine Anticommunist Alliance, a rightwing paramilitary group secretly funded by the state, assassinated one of the priests at the school in the early I970s. ${ }^{28}$ In retrospect, the emergence of multiple forms of clandestine resistance between i966 and 1969, such as the guerrilla movement, the formation of new radical unions, and the growth of the Left, could suggest that conditions were becoming ripe for organizing. Yet finding a space for political meetings was extremely difficult for Nuestro Mundo.

In addition, Nuestro Mundo struggled to find a place in the public sphere. The group sent numerous announcements to the press demanding the end of police harassment of homosexuals, but only one very small note, in the famous magazine Siete Dias, was published. ${ }^{29}$ Nuestro Mundo's first efforts to find political allies among the growing opposition to military rule were also in vain. The personal experience of Anabitarte in the Argentine Communist Party

25. See Anabitarte et al., "A 30 años" (a public lecture by former FLH activists); "Confesiones de un militante homosexual y comunista," Clarín (Buenos Aires), 8 Feb. 201 3 , p. 34; Patricio Lennard, "Elogio del chongo," Soy (Buenos Aires), 24 July 2009, p. 4; Alejandro Modarelli, "Intimas escenas del horror," Soy (Buenos Aires), 23 Mar. 20 2, p. 4; Marta Dillon, "La huella de un pionero," Página/ı 2 (Buenos Aires), 24 Nov. 2013, p. I8; Alejandro Modarelli, "Los amorales, a la plaza," Soy (Buenos Aires), 29 Nov. 2013, p. 4; Anabitarte and Sanz, Homosexualidad; Anabitarte, Estrechamente; Anabitarte, Nadie.

26. Anabitarte, Nadie, 33 .

27. Ibid., 33; Anabitarte, Estrechamente, 91.

28. Anabitarte, interview.

29. Anabitarte, Nadie, 34; "Confesiones." 
illustrates how unlikely the Left and unions were to accept homosexual men as allies. He had joined the party in 1959, and by the mid-196os he was an experienced activist. In the late 1960 s he wrote a letter demanding that the party address the situation of homosexual men. Instead of embracing his cause, however, the party leadership sent him to a Communist psychiatrist, who assured him that pathologies like homosexuality had ceased to exist in the Soviet Union, continuing only in bourgeois societies. Communism had curative properties; the psychiatrist suggested that if he wished to become normal, a trip to the Soviet Union was in order. Traveling to a faraway country in the late I 96os might have seemed an almost unattainable dream to working-class men like Anabitarte. Rather than expelling Anabitarte for being a homosexual, the party awarded him an opportunity to travel to the place he admired. In return, they expected him to become heterosexual. Considering his income and the cost of such a trip before the advent of mass intercontinental travel, it is likely that the party paid the bill, as was common at the time. He did not miss this opportunity, but Anabitarte failed to benefit from the curative powers of Soviet Russia, and he still continued to like men after returning from the tour. Moreover, Anabitarte became so assertive about his homosexuality that the party relieved him of his duties in the union and neighborhood. ${ }^{30}$ It was after being practically expelled from the Argentine Communist Party that Anabitarte began to clandestinely organize with other homosexual men from the union; together, they struggled against an intensification of police harassment under Onganía's dictatorial rule.

Nuestro Mundo demanded the abolition of so-called edicts, a body of rulings or bylaws issued by the police in violation of the constitutional division of powers. The first edicts justifying the harassment of homosexuals had been issued in the I930s, but in the I950s new edicts expanded arbitrary police powers. Under Onganía in the late i96os the situation had gotten even worse. The police had accrued extensive blacklists of so-called deviants who could be detained for a few hours or up to 30 days, depending on the mood of police officers. ${ }^{31}$ The dubious legal status of the edicts justifying such detentions did not deter a police force backed by illegal military rule. Yet although physical

30. Anabitarte, Nadie, 22-2 7; Dillon, "La huella."

3r. The FLH mocked this persecution in its published documents: for instance, see FLH, "La tía Margarita impone la moda Cary Grant," Somos (Buenos Aires), Dec. I973. The arbitrary nature of police persecution is recalled by Sebreli, Escritos, 323. For further evidence, see Acha and Ben, "Amorales"; Malva, Mi recordatorio, 6o-67; Manzano, "Sexualizing Youth." Repression did not only take place in Argentina: see Cowan, "Sex." 
brutality existed, it was not the kind of extreme violence and torture that political dissidents would face after 1976.32

By the I96os, the increasing police control of sexuality and persecution of homosexuals ran counter to the relaxation of gender boundaries and the liberalization of sexual mores among civilians, especially in Buenos Aires and other main cities. Sexual openness and gender egalitarianism were on the rise despite some efforts to the contrary by the Catholic Church, the military, and rightwing groups. ${ }^{33}$ This cultural change stemmed from multiple factors, such as the new situation of women, shifting family life and gender roles, and the rise of an innovative youth culture. Female participation in the job market was growing, and by the turn of the r970s new female professionals were consolidating their careers. Divorce would not become legal until 1985 $_{5}$, but broken marriages were becoming more visible. Male and parental power were openly discussed and some aspects of them even challenged in the educational system, the professions, and the mass media. In relation to youth culture, the changes were even more dramatic. The rising working- and middle-class standard of living since the I940s had allowed more families to send their children to high school and even college. Consumer culture targeted youngsters, offering them a new culture of entertainment, fashion, and experimentation in the midst of which a relative bending of gender boundaries became a common sight. Women wearing trousers and miniskirts could be spotted anywhere in the country. Young men en masse began to wear their hair long. These multiple transformations in the lives of women, families, and the young together forged a new culture of gender and sexuality in which alternatives to tradition were becoming mainstream. ${ }^{34}$

The opposition between the authoritarian state and the population's liberalized mores in the context of increasing political radicalization was decisive as an influence on Nuestro Mundo first and the FLH as a whole later. The struggle against police edicts first launched by Nuestro Mundo eventually became the unifying point for all the groups within the FLH, regardless of their different views about politics. And the growing confrontation between the authoritarian state and the middle and working classes made the members of the FLH think that there was not much of a difference between their fate and that of the majority of the population. This encouraged the FLH to seek allies, especially among the growing number of political dissidents during this era. To

32. Insausti, "Los cuatrocientos homosexuales desaparecidos."

33. Eidelman, "Moral católica."

34. See Manzano, "Sexualizing Youth”; Cosse, Pareja; Miller, Latin American Women; Barrancos, Mujeres. 
achieve "sexual liberation," the FLH concluded, it was necessary to join a heterogeneous "national liberation" movement and fight against the dictatorship. ${ }^{35}$ This understanding of sexual politics, however, did not develop overnight. Instead, it resulted from a gradual and at times painful collective experience.

When Nuestro Mundo issued the first bulletin under their own name to distribute among their friends, they presented a much more conservative view of sexual politics. The bulletin seems to follow what we designate a compassionate/ scientific approach, its articles emphasizing the need to feel compassion for the plight of homosexuals, which they framed as a medical condition. ${ }^{36}$ The bulletin was meant to challenge prejudices against homosexuality, but none of the articles criticized the notion of pathology. In fact, the bulletin embraced the idea that homosexuality was pathological and demanded that readers feel for homosexuals the same compassion they would have for cancer patients. ${ }^{37}$ Nevertheless, it is difficult to believe that the members of Nuestro Mundo actually bought this mix of pathologizing scientific objectivity and demands for compassion. There is no doubt that they inhabited a world in which scholars, the media, and public opinion associated homosexuality with shame and promoted curing men who desired other men. ${ }^{38}$ Nuestro Mundo expected victimhood and the embracing of homophobic science to help them as tools to challenge other views that justified police persecution. Like other homosexual

35. "Puntos básicos de acuerdo del frente," n.d., Comunidad Homosexual Argentina, Buenos Aires (hereafter cited as CHA).

36. One article copied from the New York Times praises the opening of a medical center run by Harry Benjamin for medical diagnosis and treatment of transsexuality: "Del archivo," Nuestro Mundo (Buenos Aires), Dec. 1970. Another article positively depicts drug testing and experimentation aimed at controlling homosexual desire: "Nueva experiencia," Nuestro Mundo (Buenos Aires), Dec. I970. In an interview with homosexual men published in the bulletin, one man claims that homosexuality made him unhappy: "Reportaje," Nuestro Mundo (Buenos Aires), Dec. I970. A movie review associates the life of lesbians and homosexual men with abjection: "CINE: El asesinato de la enfermera Jorge," Nuestro Mundo (Buenos Aires), Dec. I970.

37. “¿Varón o hembra? Búsqueda de la enigmática sustancia X,” Nuestro Mundo (Buenos Aires), Dec. I970.

38. Articles elsewhere in the mass media taking this approach include "Casamiento entre hombres: El tercer sexo," Revista Casos (Buenos Aires), 4 Jan. I977; "800.000 homosexuales en Argentina," Leoplán (Buenos Aires), I969, p. 42; "El día que supe que a mi hijo no le gustaban las chicas," Para Ti (Buenos Aires), I 3 Mar. 1976; "El problema de la homosexualidad," Panorama (Buenos Aires), 2 July i968; "Homosexuales," Causa y Delito (Buenos Aires), Mar. I972, p. I8; "Informe sobre homosexuales," Confirmado (Buenos Aires), Io Mar. I97I. 
men of the time, however, the members of Nuestro Mundo were part of a subculture in which promiscuity and active clandestine sexuality were ubiquitous. There was a tension between the demand for compassion and the joy that homosexual men seemed to experience in the furtive encounters widespread within male homosexual subculture.

Remembering the I960s and I970s, some older homosexual men interviewed in the 2000 provided accounts of their sexual lives that exude exhilaration rather than a search for compassion toward or scientific explanation of their deviance. ${ }^{39}$ Most homosexual encounters were hidden, but they were also ubiquitous in the public sphere. Although gay bars and discos were rare, activities like street cruising and furtive sex in public restrooms extended throughout the city. There was also flirting in some cafés, touching in public transportation, car cruising, suburban restaurants where homosexual men gathered, parties and activities related to carnival, and encounters in privately owned apartments. Sexual relations between homosexual men and straight youth were not rare, especially among the thousands of men drafted for the military who ended up in Buenos Aires and the international workforce of sailors, which was sizable before the capital port's mechanization. The men who identified as homosexual often enjoyed a wide variety of daily sexual activities, embraced femininity, and, when safe, even cross-dressed. If homosexual men hid, it was to avoid ending up in the police station for a few hours or days, but they did not seem to regret any aspect of their lives.

The articles demanding compassion in Nuestro Mundo's first bulletin thus did not fit well with the lived experience of homosexual men. In fact, the articles were not written by any of the group's members; they were transcribed from a variety of sensationalist and popularizing mass media sources. Although knowledgeable about politics and used to reading political essays, the union workers who now comprised Nuestro Mundo had never attempted to write before. Positive portrayals of homosexuality had been published in Buenos Aires by local and foreign writers since the I950s, but the members of Nuestro Mundo were not college students or intellectuals with access to these materials. 40 Their experience had provided them with a narrative for opposing dictatorial rule, but they were not prepared to discuss sexual politics. In this sense,

39. See interviews, 2005, SIGLA.

40. For examples of such positive portrayals, see Pellegrini, Asfalto; Correas, "La narración"; Cory, El homosexual. On the lack of access to such materials among Nuestro Mundo's members, see Anabitarte, interview. Anabitarte describes Nuevo Mundo as isolated from international developments, recalling how "we had no outside contacts and honestly knew nothing at that time of the developments in other countries, like the Stonewall 
the compassionate/scientific approach did not constitute a solid and longlasting ideology in Argentina, as it did for many years among American and European homosexual men of the homophile movement. ${ }^{41}$ The men of Nuestro Mundo would quickly abandon their original approach after finding an ideological alternative.

\section{Black Panthers, the Formation of the FLH, and the Rise of a Liberation Approach}

By 1970 the global and local radicalization of politics would introduce the men of Nuestro Mundo to new political views that fit their expectations better than the compassionate/scientific approach. Juan José Hernández, an Argentine poet and friend of Anabitarte, became a crucial figure in helping the group find a new direction. In I970 Hernández visited the United States and found out about Stonewall. ${ }^{42}$ Yet as influential as it was in the United States, this revolt would not be the key American influence on the Argentine FLH; in fact, Stonewall was not even mentioned in any of the reading materials circulated by the different groups comprising the FLH throughout the years. Instead, a document encountered by Hernández in New York City would become foundational for the FLH: Huey Newton's “A Letter from Huey to the Revolutionary Brothers and Sisters about the Women's Liberation and Gay Liberation Movements."43 Published by the Black Panthers in I970, this document discussed the situation of homosexuals and lesbians as a form of social oppression. Newton argued in favor of an alliance between those fighting against sexual oppression and those fighting against racism. His approach promoted a comprehensive assault on capitalism that was particularly fit for the Argentine context of political radicalization in which Nuestro Mundo was formed. For instance, the Black Panthers' politics were quite compatible with Anabitarte's own Communist background. Moreover, the Black Panthers' denunciations of racism in the United States resonated with a growing discourse in Argentina of national liberation, which identified American interests as the major obstacle for radical social transformation.

The Black Panther document provided more than a new political approach fascinating to the members of Nuestro Mundo. In their eyes, Newton's letter

rebellion." Quoted in Steve Forgione, "Living in Exile: The Story of Gay Liberation in Argentina," Gay Community News (Boston), 20 Feb. 1982, p. 7.

4r. See D'Emilio, Sexual Politics; Rupp, "Persistence."

42. Rapisardi and Modarelli, Fiestas, I 43.

43. Reprinted in Blasius and Phelan, We Are Everywhere, 404-6. 
offered a political model that for Argentina would emphasize the building of alliances with those fighting to achieve national liberation and to topple a USbacked military government. The narrative of compassion and scientific objectivity immediately vanished from the documents of Nuestro Mundo; the group had discovered a new way of doing sexual politics that articulated their concerns and experiences in a more appealing way. The letter by Newton exercised an enduring influence over Nuestro Mundo and the FLH. In October I 972 the letter was translated into Spanish and became an official FLH document. In their edition, the FLH added below the text of the letter a list of political demands, which included the freedom of all homosexuals detained by the police, the immediate abolition of all police edicts, and an expression of solidarity with all victims of political persecution under dictatorial rule. This illustrates the extent to which homosexual men in Argentina perceived their fate as tied to that of the left-wing organizations opposing the military. In I973 Newton's letter occupied most of the front page of the FLH's first newspaper. ${ }^{44}$ It was extensively distributed within Buenos Aires's homosexual subculture and among leftist political allies, and it was even republished in Chile. ${ }^{45}$

Newton's letter was only one of the many causes for Nuestro Mundo's radicalization and the formation of the FLH. Hernández also introduced Nuestro Mundo to a circle of famous homosexual writers with whom they would form the FLH one year later, in I97 I. Known as Profesionales, this group included intellectual figures like Juan José Sebreli, Blas Matamoro, and Manuel Puig. ${ }^{46}$ All these writers were in their 40 s and had already published novels, theoretical essays, and poems widely read among intellectual circles in Buenos Aires. A social theoretician, Sebreli had published his work in the most prestigious, fashionable, and respectable journals of the ig6os, such as Sur and Contorno. In 1964 he published Buenos Aires, vida cotidiana y alienación (Buenos Aires, daily life, and alienation). ${ }^{47} \mathrm{~A}$ best seller at the time, the book became a major point of reference for sociological analysis in left-wing intellectual

44. "Carta del comandante Supremo del Partido de los Panteras Negras a los hermanos y hermanas revolucionarios sobre los movimientos de liberación femenina y de liberación homosexual," Homosexuales (Buenos Aires), 7 Jan. I973, p. I.

45. Anabitarte, Nadie, 35-36. Thousands of copies of this issue of Homosexuales were published and sent to all Argentine congressmen and to some groups abroad. It was reproduced by the Chilean cultural magazine La Quinta Rueda, which explicitly mentioned the letter by Huey Newton.

46. Puig did not actively participate in the FLH, but he was in permanent communication and gave monetary support to the group. Rapisardi and Modarelli, Fiestas, I 45 .

47. Sebreli, Buenos Aires. 
circles. Puig would eventually become internationally famous for his novel $E l$ beso de la mujer araña (Kiss of the Spider Woman), which was adapted as an American musical and movie. ${ }^{48}$ In I970 he had still not written that novel, but he was already a very famous writer with two prominent novels. ${ }^{49}$ Matamoro had also published a number of influential essays. Hernández, Sebreli, Matamoro, and Puig helped Nuestro Mundo articulate a new worldview drawn from a combination of psychoanalysis, Marxism, existentialism, and avant-garde literature.

This alliance of union workers and middle-class professional writers brought together people with very different life histories. The writers from Profesionales were highly educated and had traveled widely throughout Europe in search of artistic and intellectual avant-garde inspiration. In terms of racial identity, they were descended from Spanish and Italian immigrants who benefited from upward mobility. They were mostly career oriented, and none of them were committed to any form of activism at the time that they joined the FLH. ${ }^{50}$ The union workers from Nuestro Mundo, by contrast, were experienced organizers hardened by years of struggle. While some, like Anabitarte, were of European descent, many had migrated recently from poorer provinces and were morochos, a term that describes people of darker complexion and ambiguous ancestry. This racial identity is significant within a country where white privilege has been strong and associated with national identity. Most of these unionists lived in the working-class southern outskirts of Greater Buenos Aires. ${ }^{51}$ In summary, the members of the two groups came from very different class and racial backgrounds and had different relationships with politics.

And yet despite their mutual distance, both Nuestro Mundo and Profesionales emerged amid a growingly influential left-wing political culture strengthened by opposition to Onganía's regime that cut across class and racial boundaries. They needed each other: union workers were in search of new ideas

48. Puig, Kiss; Kiss of the Spider Woman, directed by Héctor Babenco (HB Filmes, 1985); Kiss of the Spider Woman: The Musical, RCA Victor, I992, compact disc.

49. For English versions of these novels, see Puig, Heartbreak; Puig, Betrayed.

50. Puig had traveled extensively throughout Europe and the Middle East, which he wrote about: Puig, Querida familia. He also worked as a film and theater reviewer in New York, Paris, and London for the magazine Siete Días, the articles from which were compiled and published as Puig, Estertores. Sebreli presents a very similar background for himself in his autobiography: Sebreli, El tiempo.

5I. Many members of Nuestro Mundo worked for the post office or in the textile industry; one member sold typewriters, and another was an insurance agent. See Dillon, "La huella"; Forgione, "Living in Exile." Most had migrated to the capital from the hinterlands: see Anabitarte, Nadie, 33. 
that fit their experience better than the articles that they had reprinted in their first bulletins, and the writers wanted to effect social change but could not risk exposing themselves as homosexual men. The postal workers were recent immigrants to Buenos Aires, and thus their families lived far away. Their workplaces were more tolerant, and their jobs as unionized public employees were relatively safe. Against this backdrop, the union workers sought to attend demonstrations and lobby the press. 52 Alternately, even though the writers ideologically criticized the pathologization of homosexuality, they inhabited a world of middle-class professionals that exerted more pressure to compartmentalize politics, the workplace, family, and homosexual life. In their published work, the writers elaborated a general critique of sexual conservatism as resulting from alienation in a capitalist society. ${ }^{53}$ They only seldom mentioned homosexuality in their political critiques of capitalism, probably because they feared that a sole reference to the topic could endanger their careers. All of them remained in the closet with the exception of Puig, who published detailed descriptions of his sexual adventures in Siete Dias, one of the most popular magazines at the time. ${ }^{54}$ Sebreli would only publish a text openly referring to homosexuality in the early i980s. ${ }^{55}$ Even when they joined the FLH, the professional writers never really engaged in political activism beyond their secret meetings. But the difference between the two groups led not to conflict but rather to a sealing of their alliance, as this diversity allowed each to complement the other. Each group was willing and able to do what the other could not.

When Nuestro Mundo and Profesionales formed the FLH in August I97 I, the days of dictatorial rule by the military were numbered due to mounting civilian dissidence. ${ }^{56}$ In May I969, an uprising of workers and students known as the Cordobazo had taken the city of Córdoba by storm for a few days. A nationwide string of local rebellions and powerful workers' strikes followed

\section{Forgione, "Living in Exile."}

53. See, for instance, Sebreli, Buenos Aires. For an analysis of the worldview of the Profesionales, see "Homosexualidad masculina y machismo," n.d., ca. Dec. 1972, CHA.

54. Puig, Estertores.

55. See Sebreli, "Historia secreta," which was originally published in the November I4, I983, issue of Perfil. This text included the first history of the FLH.

56. The FLH produced a press release about its foundation two months after it had happened. In that document, the idea that sexual and social oppression were inherently intertwined was expressed explicitly. See "Declaración del FLH a la población de Buenos Aires," Nov. I97 I, CHA. The press release is reproduced in English in "Argentina's Gays Adopt Pink Triangle_Old Nazi Brand," Advocate (Los Angeles), 8 Nov. 1972, p. I8. The creation of the FLH was also reported by another North American gay publication:

"Argentina," Body Politic (Toronto), Autumn I972, p. I4. 
from i 969 to $1971 .{ }^{57}$ In the midst of popular upheaval, the military changed the president several times and finally bowed to popular pressure in 1973, allowing free elections with no ban on Peronism. The dramatic tension of the period from I969 to I973 created a completely different landscape for political organizations.

Nuestro Mundo had been born during the darker years of Onganía's presidency, in the late I96os, when all forms of politics were banned and thus forced underground. The FLH emerged in the early I970s, when the military had lost its ability to control civilian dissent and the return of democracy seemed imminent. The new political context, with a heterogeneous and anticapitalist Left emerging from the underground, would shape the development of the FLH in the coming years. ${ }^{58}$ This radicalization of politics came hand-inhand with further liberalization regarding gender and sexuality in civil society. ${ }^{59}$ Against this background, new organizations emerging independently joined the FLH, with new potential allies, such as feminist women, the radical youth, and left-wing groups, growing in numbers.

Feminists were crucial in helping the FLH elaborate its sexual politics. In I97 I a group of women began to organize in the Unión Feminista Argentina (UFA). ${ }^{60}$ Many lesbians joined the UFA, but for the most part they remained in the closet. Lesbian politics did not become visible in Argentina until the midI 980 , even if lesbian women played an important role in shaping Argentine culture. ${ }^{61}$ Within the UFA, discussions of lesbian politics were common, but women who felt desire for other women failed to come out to each other even in this welcoming environment. Among other goals, the UFA sought to end gender discrimination at work, demanded a divorce law, promoted gender egalitarianism, and advocated for equal distribution of tasks among men and women in the household. Together with some members from the UFA, the FLH created the Grupo Política Sexual (GPS) in 1972.62

The GPS became an intellectual powerhouse within the FLH. The group engaged in readings of Marxism and psychoanalysis and helped the FLH

57. For an analysis of the socioeconomic development of Córdoba and the social conflicts in that city between the I950s and I976, see Brennan, Labor Wars.

58. Ibid.; Tortti, "Protesta social."

59. Cosse, Pareja.

6o. Bellucci, Historia, I4I-44.

6r. Lesbian history deserves a deeper analysis of its own rather than a passing comment within a history of male homosexual politics. For an analysis of lesbian politics in recent history, see Figari and Gemetro, "Escritas"; Mogrovejo, Un amor; Gemetro, "Lesbianas."

62. Bellucci, Historia, 202-I4; Felitti, "En defensa," 56; Perlongher, "Historia," 82. 
explain the importance of incorporating sexual politics into a broader radical agenda. Such an effort to locate sexuality at the heart of social struggles was fundamental for proposing alliances with other social movements. Without sexual politics, the GPS argued, it would be impossible to transcend capitalism. A repressive social order, capitalism depended on channeling the libido into procreation. The perpetuation of domination and toil under capitalism was not compatible with the free expression of the pleasure principle. Workers would refuse to toil and women would abandon the social obligation to raise a new generation of workers if both privileged the satisfaction of their own desires. The heterosexual family, the GPS argued, was crucial in the ideological reproduction of capitalism. Families forced submission on individuals, who would accept social hierarchies as natural and unavoidable. Thus sexual repression was not just economically convenient but also at the heart of political domination. ${ }^{63}$ For GPS members, this explained why the Argentine military was concerned with both abolishing politics and policing sexuality. This was also why National Security Doctrine associated Communism with sexual freedom. The interpretation of the relationship between sexuality and politics developed by the GPS was mainly influenced by Herbert Marcuse's Eros and Civilization. ${ }^{64}$ In November 1973, the FLH's combination of Freudian and Marxist approaches was summarized in a document entitled "Sexo y revolución" (Sex and revolution). The same text would be modified and reprinted in December $1974 .{ }^{65}$

These new theoretical developments were not solely the contribution of the professional writers, union workers, and feminists. In fact, the members of Nuestro Mundo were not deeply engaged with the GPS. During 1972, when the GPS became a workshop for radical ideas on sexuality, a number of new groups of homosexual men had emerged and joined the FLH. One of these new groups, called Eros, was crucial in the rise of the combined Freudian and Marxist viewpoint. Most members of this group were radicalized college students from the School of Philosophy and Letters at the University of Buenos

63. "La moral sexual en Argentina: Investigación / Grupo de Estudio y Práctica. Política sexual," Sept. I973, Centro de Documentación e Investigación de la Cultura de Izquierdas, Buenos Aires (hereafter cited as CeDInCI), SJMP/CMS Ci/4-7.

64. Marcuse, Eros. The first edition of this book in Spanish was published by J. Mortiz in Mexico City in 1965; other editions would be published in the coming years. The book became very famous in the Spanish-speaking world, and by 1972 the well-known Spanish publisher Seix Barral had already eight editions of Marcuse's text, each with multiple reprints, that were sold throughout Latin America.

65. "Sexo y revolución,” 2nd ed., Dec. I974, CeDInCI, SJMP/CMS Ci/4-7. 
Aires. Néstor Perlongher, at the time a 2 -year-old sociology student, became the leader of this group. Though young, Perlongher already had a history of political engagement. In I970 he had joined the Trotskyist group Palabra Obrera and demanded the inclusion of the struggle against the oppression of homosexuals in its platform. When this was rejected, he left the group and began to search for fellow activists who would join him. ${ }^{66} \mathrm{With}$ other students he founded Eros in 1972, and the group immediately joined the FLH.

Between 1972 and I973, as military rule was collapsing, other groups became part of the FLH. Each had a different ideology and engaged in a variety of political activities. For instance, Alborada hosted awareness-raising meetings at which homosexual men (and sometimes a few lesbians) could talk about their past experiences and daily life to draw political conclusions about sexual oppression. At some point Alborada became the point of entrance for new members who would eventually join other groups affiliated with the FLH. Not many women joined the FLH, but a small group of lesbians formed Safo, in reference to the ancient Greek female poet. An anarchist splinter group from Eros formed Bandera Negra, included within the FLH. A group of former Catholic seminarians who had abandoned their studies because they were homosexuals also joined the FLH. They did not share the FLH's radical goals; instead of seeking the end of capitalism, they wanted the Vatican to accept homosexuality. But despite these strikingly different political views they were happy to find others who fought to present homosexuality in a positive light. Within the FLH were a variety of Christian groups, both Catholic and Protestant. The FLH's component groups rarely met together; their cellular organization granted them autonomy that helped to avoid ideological conflict between diverse and even incompatible worldviews. ${ }^{67}$

During this era of radical effervescence when many new groups merged into the FLH, the movement significantly grew in numbers and made important inroads within the homosexual subculture of Buenos Aires and its suburbs. The FLH's exact size and impact, however, are difficult to assess. None of the internal documents contain accurate numbers on activists. Moreover, it was difficult to tell who in these records were activists, because most meetings and gatherings were highly decentralized and disconnected affairs, with a large

66. María Moreno, a famous journalist and close friend of Perlongher, claims that they participated together in many events of the 1980 os underground culture. They also wrote together in the magazine Alfonsina. María Moreno, "La militancia horizontal," Página/I 2 (Buenos Aires), 27 Dec. 1998. See also Perlongher, Prosa plebeya; and the poem "Lago Nahuel," in Perlongher, Poemas, I 59.

67. "Somera cronología del FLH," n.d., CHA; Sebreli, "Historia," 334. 
number of people flowing in and out with varying degrees of involvement. What is clear is that the FLH's documents were widely circulated, and to some extent the movement was accepted as the public face of Buenos Aires's homosexual subculture. This is why the homosexual groups emerging independently after I97 I almost immediately claimed to be part of the FLH. The relationship between the FLH and homosexual subculture, however, was fraught with tensions. Most homosexual men and lesbian women found the FLH's radical sexual politics hard to understand and dangerous to support. ${ }^{68}$

Overall, the agenda linking radical social change and the overcoming of sexual repression came to prevail within the FLH, despite the fact that it often distanced the coalition from the wider homosexual subculture. ${ }^{69}$ Néstor Perlongher played a central role in this. Although very young, Perlongher was stubborn and energetic. ${ }^{70} \mathrm{He}$ had no qualms about challenging the middle-aged professionals more inclined toward intellectual debate than activism. ${ }^{71}$ Whereas writers like Sebreli and Matamoro wanted to conduct research through a survey about homosexuality, Perlongher believed that the FLH needed to find a place in the public arena through direct political intervention. ${ }^{72}$ He wanted media exposure, an alliance with left-wing Peronism, and links with feminism and other radical movements. ${ }^{73}$ The new political landscape of Argentina leading up to 1973 offered plenty of opportunities for Perlongher's political approach.

As the military was overwhelmed by civilian resistance and Argentina transitioned to democracy in I973, many members of the FLH were thrilled with a sense of newly gained freedom. ${ }^{74}$ When left-wing Peronist Héctor Cámpora was elected president in that year, the police suddenly ended the persecution of political dissidents, the enforcement of conservative morality, and the harassment of homosexual men. The FLH did not anticipate that persecution would resume only a few months later. In the eyes of many of its activists, the sudden freedom to cruise without fear of police harassment confirmed that they were right in siding with national liberation as embodied by Cámpora. On May 25, I973, Cámpora released all political prisoners, including

68. Insausti, "De maricas."

69. Ibid., 332-33.

70. Perlongher, Prosa plebeya, 7-I 2.

71. Sebreli, El tiempo, 242-43.

72. On Sebreli and Matamoro's stance, see Lennard, "Elogio." On Perlongher's, see Anabitarte et al., "A 30 años."

73. Anabitarte et al., "A 30 años."

74. "Lettera dall'Argentina," Fuori! (Turin), ı6 Apr. 1975. 
those who had organized guerrilla actions. ${ }^{75}$ The FLH had associated the fate of homosexuals with that of political prisoners because the movement understood radical social change as inextricably linked to sexual liberation. This is why they were convinced that demanding change as allies of the new regime would bring an end to sexual repression. ${ }^{76}$ Intoxicated by the new hope, the FLH invested its energies in seeking an alliance with Peronism. ${ }^{77}$

In pursuing this alliance, the FLH shifted its political agenda from one of anticapitalist social transformation to one geared toward lobbying the state for reform. Paradoxically, it was the more radicalized members like Perlongher who favored this shift. In March 1973 FLH members began to write congressmen demanding the complete abolition of the police edicts. ${ }^{78}$ In these letters the FLH explained the relationship between sexual oppression and capitalism, as previously elaborated in "Sexo y revolución," and how the end of both was necessary for national liberation. Delighted with the new regime, the FLH also sought an alliance with Montoneros, the left-wing Peronist youth movement. ${ }^{79}$

In the eyes of Perlongher and other like-minded FLH members, attending Perón's arrival at Ezeiza airport on June 20, I973, constituted a unique opportunity to be publicly noticed and achieve the political alliance that they were seeking. A group of 20 or so men from the FLH joined the mass demonstration of about 2,000,000 people waiting for Perón at Ezeiza. Such attendance was highly contested within the FLH: although enthusiastic about the end of police harassment under the new Peronist regime, many remembered the massive police raids against homosexual men launched by Perón himself in

75. See Anzorena, Tiempo, 225.

76. Tim McCaskell, "Gay Life and the Liberation Struggle in Argentina: 'We Will Conquer a Space Filled with Light,"” Body Politic (Toronto), Oct. 1976, p. 9; Anabitarte, interview.

77. See "La batalla homosexual en Argentina," Así(Buenos Aires), 3 July 1973. The FLH publicly supported voting for Perón: see "Cerremos filas," Así(Buenos Aires), 2 r Sept. I973.

78. "Carta a diputado electo por la Capital Federal," Buenos Aires, Mar. 1973, CHA. The attempt to build an alliance with Cámpora's left-wing Peronist government was not limited to sending letters to congressmen. During the two months when Cámpora was president, the FLH sent many letters to other state officials and met with them in an attempt to secure the end of police persecution. The FLH's illusion about the new possibilities opened by this government can be found in letters sent to sheriffs demanding the end of police harassment and inviting the police to join the movement for national liberation: "Circular enviada a las 50 comisarias de la Capital Federal," Homosexuales (Buenos Aires), 7 Jan. I973. See also Reunión de Grupo Profesionales, "Informaciones," 30 Apr. I973, CHA. 79. Perlongher, "Historia," 8o. 
I954. ${ }^{80}$ Once in Ezeiza, the bloodbath that followed, as right-wing Peronists opened fire and chaotic shooting from all sides left many dead and wounded, marked yet another sudden shift in the political landscape of Argentina, which in turn would reshape the politics of the FLH. ${ }^{81}$ The men from the FLH left Ezeiza unscathed, but a few days later the coalition became the target of a political attack. A front-page article in the popular magazine Asi brought the FLH's presence at Ezeiza into the public spotlight. 82 Three members of the FLH had agreed to be interviewed by $A s i$ to gain attention, but the new fame came at a high cost. ${ }^{83}$ Lieutenant Colonel Jorge Osinde, one of the organizers of the Ezeiza shootings and a prominent right-wing Peronist, used the FLH's visibility and attempt to ally with left-wing Peronism to smear Montoneros. He claimed that homosexuality and drug addiction ran rampant in the latter organization. In multiple public demonstrations, Montoneros responded to the accusation with a new chant: "We are not faggots, we are not drug addicts, we are the soldiers of Perón and Montoneros."84

At this point, the FLH realized that any hope of finding a place within leftwing Peronism had vanished. Homosexuality had become a liability for those whom the FLH had sought as allies. Moreover, after Cámpora renounced the presidency and new elections made Perón president again in October I973, the military's authoritarianism resumed with renewed strength under civilian rule. Police harassment of homosexual men became business as usual again. Funded by the regime, the Argentine Anticommunist Alliance began to assassinate thousands of left-wing activists, union organizers, journalists, intellectuals, and congressmen. ${ }^{85}$ Authoritarianism and repression of political dissidence deepened even further after Perón died on July I, I974, and his second wife, who was vice president, took command of the country. ${ }^{86}$

80. "Veinte años de razzias," Somos (Buenos Aires), Dec. I974. The police raids were also remembered abroad. In 1970 the Advocate published an article referring to the event: "Buenos Aires cops jail 300 homosexuals in one night, as politicos complain of sex deviate increase and demand return of legalized prostitution." Dal McIntire, "I 5 Years Ago," Advocate (Los Angeles), Feb. I970, p. 7.

8г. Verbitsky, Ezeiza.

82. "La batalla."

83. In Italy the Fronte Unitario Omosessuale Rivoluzionario Italiano (FUORI) saw the FLH as an example to emulate and translated the whole article. See "Lettera dall'Argentina," Fuori! (Turin), Winter 1973.

84. Perlongher, "Historia," 8o.

85. Bufano and Teixidó, Perón.

86. Anzorena, Tiempo, 297. 
Again led by Perlongher, the FLH undertook another political shift. Until Ezeiza, the focus on allying with Peronism had prevailed over attempts to politicize homosexual subculture. As this former goal became impossible, however, the FLH reconsidered its position and began publishing and clandestinely distributing a magazine aimed at homosexual men, entitled Somos (We are), that portrayed male effeminacy and sexual subversion as something to be proud of. ${ }^{87}$ Through this venue, the FLH also tried to show the homosexual subculture that a homosexual liberation movement was emerging throughout the world, reporting on its own international activities and reproducing news from Peru, the United States, Uruguay, the United Kingdom, and France. 88 FLH members also began to show up at places of homosexual socialization to deliver flyers and advice about ways to cope with police harassment. Most existing studies of the FLH focus on this stage of the organization's development because these publications exist. This stage, however, did not last long, because it came at a moment that threatened the FLH's very existence.

Since December I973, the use of homosexuality to discredit radical movements had been intensifying. After the FLH was interviewed by Así, Buenos Aires was covered with posters associating left-wingers with homosexuality and drug addiction. ${ }^{89}$ In 1975 the right-wing publication El Caudillo, run by people connected to the government, called for the "eradication" of all homosexuals by either confinement or mass murder. ${ }^{90}$ Most important, the

87. The magazine, which had eight issues, was published from December 1973 to January 1976.

88. The August 1975 issue of Somos narrates how Argentine activists attended the conference on "opresión sexual y liberación" organized by FUORI in Italy. "Oppressione sessuale e liberazione," Somos (Buenos Aires), Aug. I975, p. 4. The FLH also sent documents to the International Gay Rights Congress. "The International Gay Rights Congress," Somos (Buenos Aires), Aug. I975, p. 7 .

89. Rapisardi and Modarelli, Fiestas, I 57.

90. "Acabar con los homosexuales," El Caudillo (Buenos Aires), 2 Dec. I975. An internal document of the FLH warned that "friends: fascism has declared war against us, [fascists] propose the total extermination of homosexuals." "El facismo nos amenaza," n.d., CHA. The FLH sent a letter on April I6, I975, to the Italian queer magazine Fuori! denouncing the threat and expressing their fear, which the magazine published. The right-wing threat against the FLH was reported on and denounced in North America as well: Tim McCaskell, "Lopez Rega's Fall Eases Gay Oppression," Body Politic (Toronto), Oct. I975, p. Io. The FLH had many international connections, and the increasing persecution of homosexuals in Argentina was denounced by LGBT groups in other parts of the world. In 1975 the magazine Pa'fuera!, from San Juan, Puerto Rico, reproduced a letter sent by the FLH to the Comunidad de Orgullo Gay de Puerto Rico asking the latter to publicly denounce political persecution in Argentina. "Recrudece la opresión anti-gay en Argentina," Pa'fuera! (San Juan), Mar. I975. 
intensity of political repression was such that the FLH found it difficult to operate at the most basic level and thus decided to dissolve. A new military coup in March 1976 would inaugurate the bloodiest era in Argentine history. Some activists from the FLH, like Anabitarte and Perlongher, would flee the country. The rest devoted their energies to staying alive. ${ }^{91}$

\section{Conclusion}

The FLH faced a difficult political context from the beginning, but it was precisely that adversity that helped the movement to thrive. It was against the background of dictatorial rule and police harassment that homosexual men found it urgent to organize, even if growing authoritarianism eventually led to their movement's demise. This should be reckoned with by scholars who associate the emergence of LGBT movements with the transition to democracy. In fact, it was not only in Argentina that homosexual politics emerged in response to the rise of authoritarianism and inspired by radical politics rather than by transitional justice in new democratic regimes. Mexico's Frente de Liberación Homosexual emerged in 1971, three years after the massacre at Tlatelolco, under a formally democratic yet actually authoritarian regime that was being challenged by a radical political effervescence similar to that in Argentina. In Brazil the first homosexual political groups were formed in the late I970s, even though democracy only returned to the country in $1985.92 \mathrm{In}$ the case of Argentina, the FLH believed that the military's banning of politics and enforcement of gender/sexual normativity lacked legitimacy among the vast majority of the population. The organization thus expected to present homosexual men as victims of the same oppressive political regime affecting the entire population. In a society eager to find a new path toward social change, the FLH argued that no significant transformation was possible without sexual liberation. Rather than presenting homosexual men as a minority and demanding civil rights as such, the FLH argued that its demands were integral to achieving a deeper transformation of society and politics.

Assessing the importance of the relationship between left-wing politics and sexual/gender politics from the vantage of early LGBT movements in the late

9r. In São Paulo, Perlongher enrolled at the Universidade Estadual de Campinas for an MA in sociology. His famous 1987 ethnography of male prostitution, Perlongher, O negócio, stemmed from his master's thesis at that institution. See also "Somera cronología," n.d., CHA.

92. De la Dehesa, Queering, I6-I 7. For an excellent and detailed account of the rise of the movement in Brazil, see Green, "Emergence." 
Cold War era offers a unique opportunity to reformulate some questions in this field of study. An increasing number of scholars have focused on denouncing homophobia and male chauvinism among the Left during this era. The moral outrage implicit in this analysis might be fair: there is no doubt that prejudice regarding gender and sexuality was rampant in most unions and revolutionary movements. And yet an exclusive focus on that issue obscures the formative influence of anticapitalist and union politics on the first LGBT groups. Political reality is always complex and at times incoherent, which is why homophobic organizations played a role in the formation of homosexual liberation. Rather than analyzing this issue from the perspective of today's gender/sexual politics, it is historiographically useful to explore how homosexual activists at the time perceived this leftist homophobia. The views of many in the FLH about homophobia within left-wing organizations were quite sophisticated. There were those who believed that it could be broken, a belief that was not completely out of line. The homosexual men of Nuestro Mundo themselves had originally assumed the homophobic point of view of the compassionate/scientific approach, even when fighting to end police persecution. If they had changed, why couldn't heterosexual activists change too? The shifts in gender and sexuality happening in the wider culture at the time attested to the possibility of integrating sexual liberation with radical politics. In fact, over time and often with limitations a significant number of organizations on the left would come to embrace LGBT politics as their own.

\section{References}

Acha, Omar, and Pablo Ben. 2004-5. "Amorales, patoteros, chongos y pitucos: La homosexualidad masculina durante el primer Peronismo (Buenos Aires, I943I955)." Trabajos y Comunicaciones, nos. 30-3 I. http://www.trabajosycomunicaciones .fahce.unlp.edu.ar/article/view/TYC2004n3o-3 гa го.

Adam, Barry D., Jan Willem Duyvendak, and André Krouwel, eds. I999. The Global Emergence of Gay and Lesbian Politics: National Imprints of a Worldwide Movement. Philadelphia: Temple University Press.

Anabitarte, Héctor. 1982. Estrechamente vigilados por la locura. Barcelona: Hacer.

Anabitarte, Héctor. 2005. Nadie olvida nada. Aranjuez, Spain: Ediciones Impublicables.

Anabitarte, Héctor, and Ricardo Lorenzo Sanz. I979. Homosexualidad, el asunto está caliente. Madrid: Queimada.

Anabitarte, Héctor, et al. 2006. "A 30 años del golpe, recordamos al FLH—Frente de Liberación Homosexual.” Lecture, Buenos Aires, Argentina, i I May. 
Andújar, Andrea, Débora D’Antonio, Fernanda Gil Lozano, Karin Grammático, and María Laura Rosa, eds. 2009. De minifaldas, militancias y revoluciones:

Exploraciones sobre los $7^{0}$ en la Argentina. Buenos Aires: Luxemburg.

Anzorena, Oscar. 1988. Tiempo de violencia y utopía: Del golpe de Onganía (1966) al golpe de Videla (1976). Buenos Aires: Colihue.

Barrancos, Dora. 2007. Mujeres en la sociedad Argentina: Una historia de cinco siglos. Buenos Aires: Editorial Sudamericana.

Bazán, Osvaldo. 2004. Historia de la homosexualidad en la Argentina: De la conquista de América al siglo XXI. Buenos Aires: Marea.

Bellucci, Mabel. 20 4. Historia de una desobediencia: Aborto y feminismo. Buenos Aires: Capital Intelectual.

Blasius, Mark, and Shane Phelan, eds. I997. We Are Everywhere: A Historical Sourcebook of Gay and Lesbian Politics. New York: Routledge.

Brennan, James P. I994. The Labor Wars in Córdoba, 1955-1976: Ideology, Work, and Labor Politics in an Argentine Industrial City. Cambridge, MA: Harvard University Press.

Brown, Stephen. 2002. “' 'Con discriminación y represión no hay democracia': The Lesbian and Gay Movement in Argentina." Latin American Perspectives 29, no. 2 : I I $9-38$.

Bufano, Sergio, and Lucrecia Teixidó. 201 5. Perón y la Triple A: Las 20 advertencias a Montoneros. Buenos Aires: Editorial Sudamericana.

Corrales, Javier, and Mario Pecheny, eds. 2010. The Politics of Sexuality in Latin America: A Reader on Lesbian, Gay, Bisexual, and Transgender Rights. Pittsburgh, PA: University of Pittsburgh Press.

Correas, Carlos. I959. "La narración de la historia." Revista Centro, no. I4: 6-18.

Cory, Donald Webster. I952. El homosexual en norteamérica. Mexico City: Compañia General de Ediciones.

Cosse, Isabella. 20 Iо. Pareja, sexualidad y familia en los años sesenta: Una revolución discreta en Buenos Aires. Buenos Aires: Siglo Veintiuno.

Cosse, Isabella. 20r4. "Infidelities: Morality, Revolution, and Sexuality in Left-Wing Guerrilla Organizations in I960s and I970s Argentina." Fournal of the History of Sexuality 23, no. 3: 4I 5-50.

Cosse, Isabella, Karina Felitti, and Valeria Manzano, eds. 20 o. Los '6o de otra manera: Vida cotidiana, género y sexualidades en la Argentina. Buenos Aires: Prometeo.

Cowan, Benjamin. 2007. "Sex and the Security State: Gender, Sexuality, and 'Subversion' at Brazil's Escola Superior de Guerra, 1964-1985." Fournal of the History of Sexuality i 6, no. 3: 459-8 I.

D’Antonio, Débora, ed. 20 5 . Deseo y represión: Sexualidad, género y estado en la historia argentina reciente. Buenos Aires: Imago Mundi.

de la Dehesa, Rafael. 2010. Queering the Public Sphere in Mexico and Brazil: Sexual Rights Movements in Emerging Democracies. Durham, NC: Duke University Press. 
D’Emilio, John. 1983. Sexual Politics, Sexual Communities: The Making of a Homosexual Minority in the United States, 1940-1970. Chicago: University of Chicago Press.

Drucker, Peter, ed. 2000. Different Rainbows. London: Gay Men's Press.

Eidelman, Ariel. 20 15. "Moral católica y censura municipal de las revistas eróticas en la ciudad de Buenos Aires durante la década del sesenta." In D’Antonio 2015 , I-20.

Felitti, Karina. 2006. "En defensa de la libertad sexual: Discursos y acciones de feministas y homosexuales en los '70." Temas de Mujeres 2, no. 2: 44-63.

Felitti, Karina. 20 2. La revolución de la píldora: Sexualidad y política en los sesenta. Caracas: Edhasa.

Fernández, Máximo Javier. 20 I 5 . "Sociabilidad homoerótica en la ciudad de Buenos Aires: Maricas y marineros durante los sesenta y los setenta." In D’Antonio 20 5 , $2 \mathrm{I}-42$.

Figari, Carlos, and Florencia Gemetro. 2009. "Escritas en silencio: Mujeres que deseaban a otras mujeres en la Argentina del siglo XX." Sexualidad, Saludy Sociedad: Revista Latinoamericana, no. 3: 33-53.

Gemetro, Florencia. 20 I I. "Lesbianas jóvenes en los 70: Sexualidades disonantes en años de autonominación del movimiento gay-lésbico." In fóvenes en cuestión:

Configuraciones de género y sexualidad en la cultura, edited by Silvia Elizalde, 59-83. Buenos Aires: Editorial Biblos.

Gentili, Rafael A. I995. Me va a tener que acompañar: Una visión crítica sobre los edictos policiales. Buenos Aires: El Naranjo.

Green, James N. I994. "The Emergence of the Brazilian Gay Liberation Movement, 1977-1981." Latin American Perspectives 2 I, no. I: $38-55$.

Green, James N. 20I 2. “'Who Is the Macho Who Wants to Kill Me?’: Male Homosexuality, Revolutionary Masculinity, and the Brazilian Armed Struggle of the r96os and i97os." Hispanic American Historical Review 92, no. 3: 437-69.

Green, James N., and Florence E. Babb. 2002. "Introduction.” Latin American Perspectives 29, no. 2: $3^{-2} 3^{2}$.

Insausti, Santiago Joaquin. 201 5. "Los cuatrocientos homosexuales desaparecidos: Memorias de la represión estatal a las sexualidades disidentes en Argentina." In D'Antonio 2015, 63-82.

Insausti, Santiago Joaquin. 2016. "De maricas, travestis y gays: Derivas identitarias en Buenos Aires (1967-1989)." PhD diss., Universidad de Buenos Aires.

James, Daniel. 1988. Resistance and Integration: Peronism and the Argentine Working Class, 1946-1976. New York: Cambridge University Press.

Johnson, David K. 2004. The Lavender Scare: The Cold War Persecution of Gays and Lesbians in the Federal Government. Chicago: University of Chicago Press.

Mallon, Florencia E. 2003. "Barbudos, Warriors, and Rotos: The MIR, Masculinity, and Power in the Chilean Agrarian Reform, 1965-74." In Changing Men and Masculinities in Latin America, edited by Matthew C. Gutmann, I 79-2 I 5. Durham, NC: Duke University Press. 
Malva. 2o r r. Mi recordatorio: Autobiografía de Malva. Buenos Aires: Libros del Rojas. Manzano, Valeria. 2005. "Sexualizing Youth: Morality Campaigns and

Representations of Youth in Early I960s Buenos Aires." Fournal of the History of Sexuality I4, no. 4: 433-6r.

Manzano, Valeria. 2014. "Sex, Gender, and the Making of the 'Enemy Within' in

Cold War Argentina." Fournal of Latin American Studies 47, no. I: I-29.

Marcuse, Herbert. (1956) I966. Eros and Civilization: A Philosophical Inquiry into Freud.

Boston: Beacon Press.

Miller, Francesca. I99 I. Latin American Women and the Search for Social Fustice.

Hanover, NH: University Press of New England.

Mogrovejo, Norma. 2000. Un amor que se atrevió a decir su nombre: La lucha de las

lesbianas y su relación con los movimientos homosexual y feminista en América Latina.

Mexico City: Plaza y Valdés.

Oberti, Alejandra. 2004-5. "La moral según los revolucionarios." Políticas de la

Memoria, no. 5: 77-84.

Pellegrini, Renato. 1964. Asfalto: Novela. Buenos Aires: Ediciones Tirso.

Perlongher, Néstor. (1985) I997. "Historia del Frente de Liberación Homosexual."

In Perlongher i $997,77-84$.

Perlongher, Néstor. 1987. O negócio do michê: Prostituição viril em São Paulo. São Paulo:

Editora Brasiliense.

Perlongher, Néstor. 1997. Prosa plebeya: Ensayos 1980-1992. Buenos Aires: Colihue.

Perlongher, Néstor. 2003. Evita vive. Buenos Aires: Ediciones Eloísa Cartonera.

Perlongher, Néstor. 2003. Poemas completos: 1980-1992. Edited by Roberto

Echavarren. Buenos Aires: Seix Barral.

Puig, Manuel. (I 968) I97 I. Betrayed by Rita Hayworth. Translated by Suzanne Jill Levine. New York: E. P. Dutton.

Puig, Manuel. (1969) 20ı. Heartbreak Tango. Translated by Suzanne Jill Levine.

Champaign, IL: Dalkey Archive Press.

Puig, Manuel. (1976) I979. Kiss of the Spider Woman. Translated by Thomas Colchie. New York: Knopf.

Puig, Manuel. 1993. Estertores de una década, Nueva York '78: Seguido de Bye-bye, Babilonia: Crónicas de Nueva York, Londres y París, publicadas en "Siete Días" ilustrados, 1969-1970. Buenos Aires: Seix Barral.

Puig, Manuel. 2005. Querida familia. Vol. I, Cartas europeas (1956-1962). Edited by Graciela Goldchluk. Buenos Aires: Entropía.

Rapisardi, Flavio, and Alejandro Modarelli. 200 I. Fiestas, baños y exilios: Los gays porteños en la última dictadura. Buenos Aires: Editorial Sudamericana.

Rock, David. (1985) 1987. Argentina, I5 I6-1987: From Spanish Colonization to Alfonsin. Berkeley: University of California Press.

Rupp, Leila J. 20 I I. "The Persistence of Transnational Organizing: The Case of the Homophile Movement." American Historical Review i I6, no. 4: IOI4-39. 
Schneider, Alejandro. 2005. Los compañeros: Trabajadores, izquierda y peronismo, 19551973. Buenos Aires: Imago Mundi.

Sebreli, Juan José. (1964) I986. Buenos Aires, vida cotidiana y alienación. Buenos Aires: Hyspamérica.

Sebreli, Juan José. 1997. Escritos sobre escritos, ciudades bajo ciudades, 1950-1997. Buenos Aires: Editorial Sudamericana.

Sebreli, Juan José. I997. "Historia secreta de los homosexuales en Buenos Aires." In Escritos sobre escritos, ciudades bajo ciudades, 1950-1997, 275-370. Buenos Aires: Editorial Sudamericana.

Sebreli, Juan José. 2005. El tiempo de una vida: Autobiografía. Buenos Aires: Editorial Sudamericana.

Seidman, Gay W. 1999. "Gendered Citizenship: South Africa's Democratic Transition and the Construction of a Gendered State." Gender and Society I 3 , no. 3: 287-307.

Tortti, María Cristina. I 999. "Protesta social y 'Nueva Izquierda' en la Argentina del Gran Acuerdo Nacional.” In La primacía de la política: Lanusse, Perón y la Nueva Izquierda en tiempos del GAN, edited by Alfredo Pucciarelli, 205-30. Buenos Aires: Eudeba.

Verbitsky, Horacio. 1985. Ezeiza. Buenos Aires: Editorial Contrapunto.

Vespucci, Guido. 20 г г. "Explorando un intrincado triángulo conceptual:

Homosexualidad, familia y liberación en los discursos del Frente de Liberación

Homosexual de Argentina (FLH, I97 I-1976)." Historia Crítica, no. 43: I 74-97.

Pablo Ben is an assistant professor at San Diego State University. He studied anthropology at the Universidad de Buenos Aires and Latin American history at the University of Chicago. Professor Ben has published numerous articles on gender and sexuality in both English and Spanish. Some of his work focuses on Argentina, but he has recently begun to explore a transnational and comparative approach to studying the history of sexuality. He is currently writing a book titled "The Rise and Fall of the Cities of Sin: Male Homosexuality and Female Prostitution in Buenos Aires and Other Global Cities, 1880-1950."

Santiago Joaquin Insausti studied sociology at the Universidad de Buenos Aires, where he recently obtained his doctorate and now works as a professor. He has published a series of articles about the history of sexuality and the LGBT movement in Argentina. Professor Insausti is currently working on a book about how the transformation of homosexual identity in Argentina has shaped the change in Argentine sexual politics between the 1960s and today. 